\title{
Dejarse surcar: formas de vida
}

\section{Let Itself Be Carved Out: Ways of Life}

Castro Rey, Ignacio. Ética del desorden. Pánico y sentido en el curso del siglo. Valencia: PreTextos, 2017, 459 pp.

\begin{abstract}
El ser humano es el animal al que hay que explicar su situación. Si levanta la cabeza y mira sobre el borde de lo obvio, lo agobia la desazón por lo abierto. La desazón es la respuesta adecuada al superávit de lo inexplicable sobre lo explorado... Estar en el mundo significa estar en lo oscuro. Peter Sloterdijk.
\end{abstract}

Insistiendo en mil momentos nietzscheanos, creo que nos encontramos con una obra que, en gran medida, está construida sobre la dulzura de la contemplación, en el aura iluminada de un antiquísimo conocimiento. Su centro es la certidumbre de lo irreparable, su fatalidad, el temor y el temblor, sin evitar en este largo recorrido la inesperada alegría del instante. El texto de Ignacio Castro, expresión nítida de la era de lo discontinuo, está marcado por la heterodoxia de multitud de pensadores y artistas que quisieron crear en las zonas de sombra, en los bordes de toda posible racionalización burocrática. Tal peligro actual ya se había mostrado, entre otros, en el pensador Max Weber. Estamos ante una obra escrita al margen de esa amplia tropa de intelectuales normalizados, acomodados en una omertá autocomplaciente, que siempre estuvieron al servicio acrítico de este poder ciego que lamina cualquier posibilidad de vivir la intemperie de la propia experiencia. Tal ponzoña antihumanista destila estereotipos cocinados en los fogones de los mistagogos del materialismo positivo, con frecuencia hermanados con esoterismos meta-científicos de corte new age.

El cromatismo de autores que recorre Ética del desorden resulta apabullante. En cierto sentido, como Leibniz, Vico, Joyce o Pound, Castro establece un diálogo con el entero arco del logos judeocristiano. En no pocas ocasiones, también con Li Po, El libro del Tao de Lao Tse, las Rubayat y el carpe diem de Omar Khayyam, los Upanishads, el mundo Zen, la venerable tradición de los haiku, J. Cage o A. Watts... Cerca siempre de Heráclito, Castro busca la flexibilidad de la tensión en algunos de los grandes místicos o poetas a los que se tiende a reducir, de forma holística, bajo el epígrafe del "pensamiento oriental". Dicha uniformización, un tanto ingenua y opresiva, ya fue desmontada por Said en su iluminador Orientalismo. 
Castro Rey es consciente de que la profesión de fe, histórica en Israel, y la creatividad poética y filosófica de Grecia, con excepción de la vocación mesiánica judaica, han devenido en dos caras de la misma moneda. Aunque más al este civilizaciones refinadas construyeron panteísmos herméticos profundamente reflexivos, vitalistas, de asombrosa sabiduría y ajenos a toda inquietud democrática, pero atentos a aquello que está dormido dentro de nosotros.

«Curiosamente son los místicos, llevando al extremo la experiencia de lo transcendente, quienes hacen de la fe una experiencia subversiva, mundana y corporal, erótica y estética». (pág.195)

Castro explora la primacía del pensamiento autárquico, sobre la democracia, en medio mundo. Allí donde la politeia es delegada en manos de sutiles burócratas, eficacísimos en la consolidación del poder de sus amos. Frecuentemente crueles, representantes de poderes incontestables y casi semidivinos, tales personajes son obedientes herederos de una dureza atávica que dibujaron muy bien I. Andrić o I. Kadaré. Algo así podría ayudar a entender la "envidiable" estabilidad y rocosa sabiduría de Rusia, China, Irán o de los países árabes, que tanto nos perturban moralmente en occidente. Por cierto, en la visita del inefable Donald Trump a China, no habló ni una vez de Derechos Humanos o de democracia. Él estaba allí para hacer negocios, para reestructurar la balanza comercial entre ambos países con una realpolitik que se pasea por la Ciudad Prohibida y no tiene ni un segundo para Tiananmen, tema tabú impuesto por el gobierno chino en todas sus relaciones internacionales. Occidente tiende, bipolarmente, hacia el relativismo. La usura sigue pervirtiendo el ser del mundo:

«Con usura el hombre no puede tener casa de buena piedra con cada canto de liso corte y acomodo [...] con usura no hay para el hombre paraísos pintados en los muros de la iglesia $[\ldots]$ no se pinta cuadro para que dure y para la vida sino para venderse pronto [...] con usura es tu pan como el papel, sin trigo de montaña, harina fuerte $[\ldots]$ Usura oxida el cinc [...] Oxida el oficio y el artesano. Roe los hilos del telar. Nadie aprende a tejer oro en su dibujo; El azur tiene una llaga por usura; el carmesí sin bordar se queda». (Canto XLV, de E. Pound)

"El don es bueno; la rapiña mala, dadora de muerte», recuerda Castro citando a Hesíodo. Dar es bueno; principio caritativo de unas religiones del Libro que casi nunca están a la altura de sus autoexigencias.

En Ética del desorden Ignacio Castro sigue fiel a los pensadores con los que nunca ha dejado de dialogar. Pero cierta necesidad ontológica, la de fundir el sistema con la insignificancia de lo que aparece, lleva ahora a otorgar un mayor peso conceptual a creadores como W. Whitman, H. Thoreau, M. Stirner, S. Weil, C. Lispector. Más un siempre renovado Rilke, los helenistas, Joyce, Spinoza, Leibniz, Berkeley, Unamuno, Borges, Wittgenstein... y una larga lista que incluye autores tan actuales como Walser, J. Crary o Byung-Chul Han. Sumémosle a esto la interpretación de algunas excelentes películas contemporáneas que hacen que el lector sienta 
una nueva frescura en esta siempre mordiente escritura. Palabra exigente, potencia polisémica, atenta a las luces y sombras del instante que sondea los laberintos de nuestro suelo cotidiano... El hilo conductor de este pensamiento sigue siendo la crítica radical de lo que podríamos denominar una tolerancia ilustrada, enrarecida por la construcción de consensos blandos -al modo de Habermas- que casi siempre se validan en nombre de una doxa pragmática que no tiene ojos, oídos, ni alma, para nada que se mueva fuera de ella.

La primera víctima del consenso y la paz social es la verdad. No hay más que pensar en los refugiados, víctimas de múltiples guerras, y el rechazo que provocan en multitud de gobiernos y en no pocos ciudadanos; cuestión de primer orden, y determinante, en todas las elecciones, de los países mediterráneos y del centro y este europeo. Primacía acrítica de una intersubjetividad mayoritaria que suele conducir hacia la creencia en una legitimidad no variable.

«El simple peso de las muy distintas culturas en la actualidad, en las hostilidades y empatías que persisten, indican el peso de lo natal en el mundo. Bajo las comprensibles ilusiones, no hay más universalidad que la de lo individual [...] Es suicida entender la libertad como una elevación, un despegue, una huida de la infancia y los sitios que nos han configurado.» (pág. 446)

La propuesta es sencilla: asumir nuestro signo natal como algo indescifrable y ser capaces de darle forma a una vida no elegida, de tal modo que mereciese la pena volver a ser vivida:

«Lo máximo que podemos hacer es prepararnos para lo desconocido». (pág. 305).

Cercano a la Stoa, todo este libro está recorrido por la idea de una revolución permanente que implica, primero, aceptar lo irremediable.

«La deformación que producen las contingencias es lo que en el fondo nos forma, enseñándonos una y otra vez la ley irregular de lo real, su azaroso orden.» (pág. 241)

Todo es sin razón... o con otra razón. Desconocida raíz común. No se trata de predestinaciones esotéricas ni de mantras neomarxistas, sino del cauce que marca toda existencia. Se trata de la conversión permanente sartreana o de la insurrección permanente del hombre rebelde de Camus. La vida puede colapsarse de repente, cualquier cosa nos puede ocurrir en cualquier momento. Lo inesperado es omnipresente y lo rodea todo. Tienes unas expectativas y, en un instante, todo cambia, se mueve y probablemente ese giro azaroso tenga un efecto determinante en tu vida. Esta idea no encierra negatividad alguna, pues lo inesperado suele ser beneficioso en una mutación, aunque parezca en principio recesiva. Uno puede enamorarse y ser correspondido, pero nadie sabe si en el futuro estará en el cielo o el infierno. Limpias un arma y hieres a tu hijo. Paseas por la montaña y un efecto climatológico extraño complica las cosas. Tiendes una mano y eres abrazado o despreciado. 
«¿Después de la muerte? Después de la muerte "no hay nada", pero no porque estemos convencidos - por un materialismo positivo- de que la vida se acaba aquí y "después" solo resta el silencio. El problema es más bien que la muerte es algo tan enorme, tan vivo y latiente, que no admite un "después”.» (pág. 344)

Ética del desorden, en su ontología, es un texto más espinozista que sartreano. En él la vida fluye impregnada de enigmas involuntarios, consciente de que las civilizaciones, culturas o genes están determinados por el riesgo de posibles mutaciones recesivas. Incertidumbres vitales que Lacan denomina "síntoma" y donde el gran Sartre, un tanto cándido, quiso ver una libertad existencial negativa, sin dejar rastro para ese espacio en el que Spinoza cuestiona la idea de una libertad absoluta, inmune al pasado y presente no elegidos de cualquier existencia. En un potente análisis, entre lúcido y mistificante, y en un clima de desorientación posbélica que profundiza aún más en la era de la conciencia desgraciada, Sartre propone un pathos de libertad de acción en el que el hombre es un ser que procede de una elección absoluta de sí mismo, estando condenado a la libertad. La indecisión ante el vacío, teorizada por Castro Rey, nos sitúa siempre ante un final abierto, en dirección a un nuevo comienzo. Impulsados por una tensión bipolar y conscientes de que aún lo más contiguo es algo muy remoto para el hombre, tal y como poetiza Rilke en la octava elegía de Duino. Una separación, que nos habita y nos constituye, impone que la primera damnificada es esa libertad absoluta y negativa preconizada por el gran pensador existencial.

El proyecto filosófico de Ignacio Castro Rey es hoy difícilmente comparable. $\mathrm{Y}$, sin embargo, en cierta forma, corre el peligro que antes transitaron Platón, Leibniz, Hegel o Nietzsche: desentrañar el sentido inmortal de la totalidad mortal:

«He intentado escribir el paraíso». (E. Pound, Canto CXX)

«Hoy solo el Apocalipsis puede liberarnos. Hace falta otro impacto silencioso y poético, que nos despierte del estruendo de la cronología». (pág. 251)

Seguro que Castro no piensa en un Termidor, sino más bien en que toda impureza procede del futuro, cuestionando el axioma del progresista dialéctico, más o menos secularizado, que sigue afirmando que el presente es el lugar donde se tacha el pasado y se inventa el futuro. El pasado como pesadilla, el presente como desilusión y el futuro como liberación. Algo de esto intuyó W. Benjamin en su comentario al Angelus Novus de P. Klee: Lo que llamamos progreso es justo esa tempestad. Otra vuelta de tuerca al nihilista Estado de excepción permanente. No hay futuro, no hay futuro, el futuro somos nosotros, vociferaban los Sex Pistols o Joy Division, haciendo de su rabia un himno para jóvenes desesperanzados.

«Todo creador es un superviviente, alguien que ha respirado las grietas de una presión asfixiante.» (pág. 419)

Al igual que Schopenhauer en Parerga y paralipómena, o en El mundo como voluntad y representación, Castro Rey quiere pensar la más ordinaria vida común. Pre- 
tende pensar el amor, la belleza, la justicia, la verdad, el sexo, los sueños, la sabiduría popular. Experiencias ligadas a aquello infranqueable que tanto desasosegaba a Pessoa, Wittgenstein, Cioran, S. Weil, Juan de la Cruz o Teresa de Ávila.

«Todo sentido real roza las sombras, se presenta cargado de ambivalencia y espectros.» (pág. 139),

recordándonos una de las obsesiones de Shakespeare o del último Auster:

«[...] hablo con fantasmas todo el tiempo, claro que no en voz alta».

La vida nunca está en otra parte:

«Todo es exterior, podríamos decir, cuando el interior se reduce al rumor de un desierto». (pág. 69)

Quizás nos hemos sentido acongojados demasiado tiempo por el pecado, el perdón, la obediencia, la santidad, el miedo pueril hacia la doctrina del peccatum originale. Todo ello basado en la racionalización del relato bíblico de la expulsión de Adán y Eva junto con su pueblo, y a la que han dado forma en el imaginario colectivo occidental grandes místicos como Orígenes, Pseudo Dionisio, Agustín, marcado por sus inicios maniqueos, y toda la teología medieval sin excepción. Ellos configuran una forma de vida deudora de un concepto de culpa, una voluntad de pureza transcendente que no está presente en el helenismo. Para Séneca, poseerse a sí mismo es tarea de toda una vida de meditación y autoanálisis. Somos hijos de la intemperie, no de un inmolarse en una cadena de complejos castradores, un platonismo de la huida que Nietzsche denuncia como motor de Occidente desde el siglo XIX. Es posible que ese imperativo categórico del haz lo que debes haya desplazado como un anatema herético el vibrante haz lo que deseas, no renuncies a tu deseo. Encontrar un equilibrio entre ambas formas no es tarea fácil, como nos muestra Lacan en su Kant con Sade, pues todas las teorías que se auto-reivindican como las más sanas, las más normales o naturales, son sospechosas de enfermedad y patologías ocultas. Pero acercarse a eso sí puede otorgar serenidad y sentido, en nuestro día a día, frente a la abrasiva oferta de experiencias y objetos de consumo y goce, incluso más allá de cómo podrían ser satisfechas con mercancías realmente producidas. Los compases de The Future, de D. Byrne, dan el salto desde la distopía artística a la mimetización con una sociedad cada vez más ultrajada e insatisfecha. ¿Alguien puede no seguir tomándose en serio al Freud de El malestar de la cultura?

Ética del desorden. ¿Nos encontramos ante una obra de baja intensidad afirmativa, escéptica, con la que debemos evitar el acuerdo o desacuerdo? Tal vez incluso deberíamos distanciarnos, separarnos de su literalidad, de su magnetismo seductor. ¿Acaso no es esa la única manera de leer con libertad la tensión agustiniana de La ciudad de Dios, ese masoquismo metafísico de origen paulino, antiguo zelote anticristiano, único en su capacidad de crear sentimientos de culpa? O sus Soliloquios, impregnados de una generosa introspección melancólica. O el nihilismo 
de Nietzsche, en su búsqueda de una segunda inocencia no culpable, o en cualquier otro "ismo" clásico.

El asombro del lector en este libro es permanente. Belleza inmarcesible en una escritura pulidísima, lectura casi irrespirable en su radical osadía, en su impertinencia afirmativa, sembrando más dudas que costras duraderas. La concentración hacia las cosas mismas -epojé- de este pensamiento resulta tan exigente que obliga al lector a tomar una decisión fundamental: como en Rayuela, leer de principio a fin sin tregua posible; leer este libro atenta, pero tangencialmente, incluso de forma intermitente. O bien disolverse, demorándose azarosamente en esa articulación de mantras aparentemente inexpugnables. Correosos juegos de lenguaje, engastados en la convicción de que

«El trabajo personal, moral y político de la percepción es captar los detalles del mundo antes de que sean ya un código establecido». (pág. 69)

En este libro pensar, que se convierte en una forma de vivir, sentir, crear, no deja de ser una cuestión de forma, un tachar incesante. La voluntad de estilo es, en todo caso, una decisión seria y meditada, resultando un imperativo filosófico cuando el pensador se enfrenta a aquello que puede ser pensado y no puede ser conocido.

«QQuién no sintió la angustia de sentarse ante el retablo de su propio corazón?», leemos con Castro (pág. 223)

en la cuarta de las Elegías de Duino. Ello implica esforzarse en simplificar y buscar esa clara dureza que anhelaba Heidegger y que en ocasiones hacen inevitables los rodeos. Saber elegir las palabras, para expresar una idea, puede exigir una catarata de sentimientos, vivencias, imágenes. O una exhibición de complejos, en busca de la desnudez más absoluta. Todo hombre ha tenido su hora, escribe Rilke. Toda vida ha de someterse a examen en algún momento. El cosmos como escritura, propone Cirlot.

Ya nos recordaba Jünger que solo la sinceridad puede producir cambios. En el polo opuesto de la austeridad monacal del genio de Wittgenstein, Ignacio Castro recuerda la disciplina de Léautaud, quien escribía sabiendo lo que iba a escribir y tras haberlo pensado lo seguía pensando y prefería no hacer nada a ignorarlo o no escribirlo. Pequeñas frases duras y apretadas, cargadas de destellos efímeros; fragmentos únicos y múltiples, pequeñas vidas eternas y sin límites, rigor presocrático, rudeza campesina, alianza entre pensamiento y poesía, renglones quintaesenciados... Un portento inagotable de ensueño y transparencia luminosa que, en ocasiones, tropieza con una fatigosa proliferación de notas. Aunque Castro no parece querer renunciar a la presentación del árbol genealógico de su filosofía, de la que incluso, después de la publicación de su texto, propone Un indice necesario (publicado en su página web). Texto soberbio de un letraberido que sabe que en un principio no fue la palabra, sino la extrañeza en busca de palabras... sin necesidad de gramática alguna. Todo lenguaje es anticipado por el contacto físico, por el murmullo perceptivo, por la necesidad de los otros y sus caricias reparadoras. La 
gesticulación, el aullido, los sonidos guturales espasmódicos, ceden terreno ante el misterio de la proximidad humanizadora, ante el deseo de una quietud no violentada. Tormenta abstracta del afuera (p. 49):

«Nunca tocamos nada sin, a la vez, tener sensaciones abstractas».

En cierto sentido, estamos ante un libro cruel. Se suceden los comentarios, los pensamientos, los aforismos, las imágenes... Perlas únicas. Las montañas ofrecen más descanso. En la medida que carecemos de un índice temático, construir un oscilograma inconsciente durante su lectura ayudaría a delinear sus múltiples encuentros y puntos de fuga.

A Foucault y Derrida les gustaba hablar de filosofía robada, de un apropiarse de la escritura de otros, y en Ética del desorden los ejemplos de esto son múltiples. Pero las referencias adquieren otro color, distinto contexto, nueva vida. Este ejercicio de demolición y deconstrucción no es otra cosa que la Historia de la Filosofía, manteniendo viva la siempre inconclusa conversación que es Occidente. Leer siempre fue releer, escribir es reescribir y conocer es recordar. Ninguna lectura tendrá que reproducir un significado original; tampoco un sentido privilegiado o fundante, ni una evidencia inicial que la palabra representaría. Toda hermenéutica debe ser una deconstrucción creativa de palabras, discursos, sistemas, en la línea de Gadamer o Steiner. Como afirma Cristina de Peretti Della Roca, comentando el "Nietzsche, Freud, Marx" (1967) de Foucault, las palabras provocan nuevas palabras, los discursos nuevos discursos. No existen significados originales. Tan solo interpretaciones entrecruzadas que se implican en una red infinita que nunca se clausura y que debe estar tejiéndose permanentemente. Al solitario de Sils Maria le gustaba decir:

«El lector perfecto, tal como yo lo imagino, es un monstruo de valentía y curiosidad, con una dosis de ductilidad, astucia y cautela, un aventurero y descubridor nato».

Algo así recorre Ética del desorden. El lenguaje, entendido como signo de vida, opera dudando de sí mismo, en el filo sutil de un silencio que no duerme (Lispector). Disociación que, según el Steiner de Presencias reales, abre el camino hacia el solipsismo y la duda; abismo infranqueable entre percepción y designación que solo puede ser parcheado por el poema. Posición que desgasta el sentido común y lo suplanta por una perspectiva vitalista que va más allá de todo lenguaje figurativo. Indigencia del sentido que recorre toda la obra que hoy nos ocupa.

«De ahí que el arte -y no solamente para Nietzsche- es el único gran remedio del sufrimiento, la única forma de ser fiel a la profundidad de las superficies. El silencio siente, sufre, conspira. Su profundidad no tiene más remedio, para seguir careciendo de nombre, que advenir a la superficie y adquirir un rostro.» (pág. 215)

Superación del frecuente parloteo afásico, al que solo se puede combatir desde un silencio ensordecedor. El lenguaje existe antes que la gramática. 
Lo mismo es ser y pensar, nos recuerda una y otra vez Castro Rey. Y esa vieja certeza universal, a la que dedicó páginas inolvidables Heidegger, se nutre de un orden secreto, oculto y omnipresente que se resiste a olvidar el estrecho vínculo que existe entre ética y alegría. Curiosamente, en su primer discurso público al llegar a Colombia, el Papa Francisco enfatizó «QQue no os quiten vuestra alegría!». Sin querer banalizar las tremendas injusticias y crímenes del nuevo orden mundial, esta afirmación resulta transgresora. Es también una idea presente ya en el cristianismo de los eremitas biografiados por Paladio, en el helenismo y en Nietzsche. Distintos tonos, distintas experiencias, apuntan a una idéntica verdad ontológica: construir una imagen del mundo y fundirse con ella. Demorarse en la serenidad, en la impaciente paciencia, en los tiempos muertos, en una alegría que no olvida la memoria de la pobreza. Que cada uno ocupe su lugar. El tiempo remata entonces en cada aliento y a todos nos ha de sobrepasar el portal (Thorweg) de nuestros instantes. El trabajo personal, moral y político de la percepción es captar los detalles del mundo antes de que sean ya un código establecido:

«El instante de revelación significa una sintaxis idéntica al desorden del día, una gramática auténticamente generativa (Chomsky): esto es, generada por el propio desorden de la inmediatez, la corriente de un aquí y ahora». (pág. 256)

Tal pulsación del tiempo nos recuerda que la tarea más profunda del pensamiento es librarnos del pensamiento (pág. 256).

«Hay que sufrir y sentir antes de pensar. Si no destruimos el pensamiento, el pensamiento nos destruye.» (M. Stirner)

Bucle que nos recuerda que vivir, escribir, conversar, pasear, pintar, orar, componer, pensar, jugar, amar, es olvidar, improvisar, darle forma sensible a las sendas solitarias y comunes de la percepción. Es entregarse a la errancia de la duda, a las preguntas sin tiempo. Poder ser común siendo distinto. Alli donde todo lo intelectual deviene en acto, en gesto. Vivir es muy difícil, no menos que morir, y la infancia, inevitablemente, retorna siempre y nunca deja de estar ahí (Freud). Es clave el amor que hayas recibido de tus padres, como quiera que lo hayan expresado. En gran medida de ello depende nuestra cordura, nuestra niñez adulta; una vez más, la dualidad entre olvido y reminiscencia. Nos volvemos a situar ante un azar irremediable, ante el enigma de toda existencia.

«Claro que la infancia no se fue. ¿Adónde iba a ir?» (san Agustín p. 32)

¿A dónde se va la luz cuando apagamos una bombilla?, se interroga el niño fascinado por las estrellas y los misterios del universo.

Soy consciente de las generalizaciones y abstracciones con las que abordo el espesor ontológico de Ética del desorden, pero no es mi intención entrar en detalles discursivos, sino mostrar el estado de ánimo de una lectura que no entra a polemizar con las grandes cuestiones que recorren este texto: el amor, la belleza, la verdad, el 
sexo, el enigma, la percepción, Dios, el azar, la modernidad, el determinismo, el tiempo, la muerte... Aprender a no ser imprescindible no evita el necesario imperativo de pensarse, quererse a sí mismo, como única posibilidad de comprender a los otros. Quizás una temporada en los jardines de Epicuro pueda sustituir la preocupación por los demás con la preocupación por uno mismo. Tal vez podamos volver a encontrar la llave que nos permita vivir con cierta alegría pueril en esta comunidad inconfesable que, a pesar de su aspereza, nos incita a aspirar lo imposible a través de rodeos en apariencia inútiles.

Lean este libro de Ignacio Castro; una propuesta filosófica insólita, maciza, fecunda y gozosa, vitalista e impregnada de una libertad romántica muy actual, a pesar de los rastros de Hegel. Estamos en compañía de una obra distanciada de ese espíritu de venganza y posverdad que encontramos como dogma allí donde dirijamos la mirada. Un largo ensayo crítico con el mito del proceso civilizatorio jacobino, uniformizado en comunas de hombres liberados de sus cadenas que no tardan mucho, a su vez, en convertirse en portadores de cadenas. Las revoluciones tienden a traicionarse a sí mismas. Histéricos y neuróticos compulsivos, por decirlo en términos psicoanalíticos, fanatizados religiosamente, Rousseau, Robespierre, Fouché... dispuestos a construir una dictadura de redentores, alimentándose de todos los fantasmas de venganza que se enrocan por doquier. En nuestro horizonte audiovisual, el auténtico género de terror, que supera el nivel de demonización nominal que ejercen los medios, no muestra casi nunca la cara del monstruo. Pero no solo para mantener el negocio del suspense, sino también por razones metafísicas. Lo monstruoso es lo que está ahí, pero no se muestra: esos verticales silencios, dice Debray, nacidos en el ruido horizontal de la comunicación. Cada sociedad, desde su episteme parcial y excluyente, está casi obligada a repetir una vieja pregunta:

«¿Quién de nosotros no es de los nuestros? Nuevos perfiles potenciales prolongan así la sombra del judío, del pagano, del cristiano, del islamista radical, del hereje. El espía, el marciano, el terrorista, el extranjero, el antisemita. El que no es británico, o no es ruso ni francés, solo son epítomes de un universal terror a lo exterior. Pero como en esta sociedad de infinitos interiores es lo real mismo lo que se ha vuelto extraño, nuestra lista interminable de enemigos repite y prolonga el miedo a lo indefinido, la zona umbría que es la pulpa de lo real». (pág. 77)

La nave espacial de nuestra globalización apunta hacia la neutralización de todo heroísmo; a la marginación de todo outsider que no se haya emboscado a tiempo. Hoy, quizás como nunca, hay motivos para sospechar de un entorno monstruoso y fagocitado, en el que se intercambian la guerra fría y la paz caliente, a gusto de la posverdad, en una pavorosa y masiva alianza entre "chusma y élite", que Canetti caracterizaba como un fenómeno tan enigmático como universal.

La era de la cultura espectacular inaugura un nicho dramático, una factoría cultural de ensoñación y angustia en la que la veneración de las virtudes vengativas se impulsa hacia cotas inimaginables. A todo ello solo nos podremos oponer resistiéndonos a salir de la jaula giratoria de los pensamientos, callar y no olvidar la posibilidad de ser dueños de nuestra existencia, de tal modo que nuestra vida merezca volver a ser 
vivida; propuesta no tan alejada de la eudaimonía aristotélica que alcanza su mayor punto de esplendor y melancolía con el Helenismo.

Ante la crisis de la concepción mesiánica de la historia, y matizando a Heidegger, intuimos que el Dios transcendente no existe, pero insiste: su consuelo puede acompañarnos porque ya no puede salvarnos. Hay que cambiar de vida, nos propone un Castro Rey fascinado por el aura de Rilke y sopesando inconscientemente, como posibilidad no explicitada en su libro, pensar la Demostración de la Proposición 8 de la Ética de Spinoza: toda substancia es necesariamente infinita; lo cual sería una forma audaz de abordar el eterno retorno de lo mismo. Con el peso más pesado de esa desconocida raíz común que no cesa piensa y vive este libro que acabamos de cerrar. Mientras sigue abierto:

«El último fulgor del día se detiene a esperarme». (W. Whitman)

Rafael J. Varela Nogueira. Vicedirector del Grupo de Trabajo de Filosofía para las ABAU-CIUG-USC. Profesor de Filosofía en Enseñanza Secundaria 